\title{
Effects of Blood and Urine on Lead Analyzed by Flameless Atomic Absorption
}

\author{
By R. J. Shamberger \\ The Cleveland Clinic Foundation, Cleveland, Ohio, U.S.A.
}

(Received May 7/October 15, 1982)

Summary: About a 10-15\% difference was observed by comparing (CDC) bovine blood to a lead standard addition curve using human blood. Results similar to the mean of the CDC survey were obtained by adding lead directly to the bovine bood using standard addition techniques. These results indicate that standard additions of lead should be made to the same matrix and that matrix effects can occur when blood from different species is compared. Analyses of both CDC bovine blood and human blood with added Triton X100 showed greater sensitivity and reproducibility than similar blood without added Triton X-100.

$\left(\mathrm{NH}_{4}\right)_{2} \mathrm{HPO}_{4}$ greatly enhanced the signal height of lead in urine while nitric acid had a much less effect. The enhancement by $\left(\mathrm{NH}_{4}\right)_{2} \mathrm{HPO}_{4}$ of the lead signal was at final concentrations greater than $10 \mathrm{~g} / \mathrm{l}$. At less than $10 \mathrm{~g} / \mathrm{l}$ enhancement rapidly decreased. Triton X-100 did not enhance the signal height of lead in urine. Calcium ion and chloride ion did not decrease the lead absorption peak in urine, but magnesium ion did decrease the height of the absorption peak in urine.

\section{Wirkungen von Blut und Harn auf die Analyse von Blei mit flammenloser Atomabsorptionsspektrometrie}

Zusammenfassung: Eine Differenz von etwa 10-15\% wurde bei Vergleich von CDC-(Communicable Disease Center, Atlanta)-Rinderblut mit Menschenblut für das Erstellen einer Standard-Additions-Kurve für Blei beobachtet. Ähnhliche Ergebnisse wie für das Mittel des CDC-Ringversuchs wurden bei direkter Zugabe von Blei zu Rinderblut mit der Standard-Additions-Technik erhalten. Diese Ergebnisse zeigen an, daß Standard-Additionen von Blei zur gleichen Matrix erfolgen sollten und daß̣ Matrixeffekte auftreten können, wenn Blut verschiedener Species verglichen wird. Analysen sowohl von CDC-Rinderblut als auch von Menschenblut zeigten nach Zugabe von Triton X-100 eine größere Empfindlichkeit und Reproduzierbarkeit als diese Proben ohne Triton X-100.

$\left(\mathrm{NH}_{4}\right)_{2} \mathrm{HPO}_{4}$ erhöhte bei Endkonzentrationen $>10 \mathrm{~g} / \mathrm{l}$ das Signal für Blei im Harn stark, unter $10 \mathrm{~g} / \mathrm{l} \mathrm{nahm}$ die Erhöhung stark ab, während Salpetersäăure eineñ sehr geringen Effekt zeigte. Triton X-100 erhöhte das Signal für Blei im Harn nicht; Calciumionen und Chlorid verminderten es nicht, während Magnesiumionen es verminderten.

\section{Introduction}

Lead in the environment is a serious national concern especially in the inner city where children may ingest as much as $1 \mathrm{mg}$ from a small paint chip. Although lead values up to about $40 \mathrm{mg} / 1$ of whole blood are considered normal in most laboratories and $40-60 \mathrm{mg} / \mathrm{l}$ as borderline exposure, Needleman et al. (1) have postulated that neuropathies and borderline retardation may start in susceptible individuals at lead levels we now consider normal or borderline. Because of a growing national concern, more knowledge about lead procedures is desirable.

The lead atomic absorption signal is strongly affected by constituents in the biological matrix. The ob- 
ject of these experiments is to optimize the lead signal of whole blood and urine by altering the matrix. In addition, by comparing the results from standard Communicable Disease Center (CDC) samples analyzed by other types of flameless atomic absorption to the results from Zeeman effect graphite furnace spectroscopy, we wished to test whether Zeeman effect graphite furnace spectroscopy would be adequate for lead analysis.

\section{Materials and Methods}

\section{Apparatus}

A Hitachi Model 170-70 Flameless Atomic Absorption Spectrometer (NSI Hitachi, Mountain View, CA 94043) is equipped with a low UV sensitive Hamamatsu photomultiplier tube, R955 (Hamamatsu Corp., Middlesex, NJ 08846). A quartz rotating Senarmont polarizer, placed between the graphite cuvette and the hollow cathode lamp, polarizes the radiation alternately perpendicular and parallel to the magnetic field produced by a 1.1-T $(11 \mathrm{~kg})$ magnet. Hitachi (Naka Works) cup-type cuvettes were used for all analyses (Nàka Works, Hitachi Ltd., Katsuta Ibaraki, 312, Japan). The Zeeman Effect Atomic Absorption signals were recorded on a Hitachi fast response, dual pen recorder, Model No. 056. The second pen allows simultaneous monitoring of the background absorption so that it remains below the maximum correctable value, 1.7 A. Koizumi et al. (2) have described in detail the theory of Zeeman-effect flameless atomic absorption spectroscopy.

The spectrometer unit has two gas flow systems. The first, a sheating system protects the furnace assembly and electrodes from oxidation. The second flow system, the carrier gas, flows from the ends of the cuvette to the middle. This tends to keep the metal vapor in the magnetic field. A Laboratory Crest 0 to $100 \mathrm{ml} / \mathrm{min}$ flowmeter (Lab Crest Scientific Glass Co., Warminister, PA 18974) regulates the flowrate of the carrier gas. Argon gas is used for both flow systems.

\section{Experimental}

\section{Reagents and vials}

Working lead standards, $1 \mathrm{mg} / \mathrm{l}$, were prepared from a $1.0 \mathrm{~g} / \mathrm{l}$ Fisher Scientific Atomic Absorption Lead Standard. The diluent used for preparation of $1 \mathrm{mg} / \mathrm{l}$ working standard for the blood lead analysis was distilled deionized water. Fisher Scientific (Pittsburgh, PA 15219) polyethylene sample vials were used for dilutions. All vials were soaked overnight in $1 \mathrm{~mol} / \mathrm{l}$ nitric acid (ASC reagent grade; Fisher Scientific) and rinsed several times with distilled deionized water before use. "Ultrex" grade $700 \mathrm{~g} / \mathrm{kg}$ nitric acid (J. T. Baker Chemical Co., Phillipsburg, NJ 08865) was used for assays. Triton X-100 was purchased from Sigma Chemical Co., St. Louis, MO 63178. Diammonium hydrogen phosphate, ACS Reagent grade came from Fisher Scientific. Only barely detectable amounts of lead were observed in the Triton and the diammonium hydrogen phosphate and there was no lead detectable in the Ultrex nitric acid. NBS Bovine Liver Standard Reference Material, SRM 1577 (National Bureau of Standards, Washington, D.C. 20234).

\section{Procedure}

Whole blood specimens were collected in Beckton-Dickinson Minimal Lead Vacutainers which contained heparin. Human blood, CDC bovine blood or Toxi-E1 standards 1,2 and 3 (A. R.
Smith) were transferred with an Eppendorf pipet and then diluted 1:10 with distilled deionized water. Two types of experiments were done. First of all, human blood was diluted 1:10 with distilled water or $1: 10$ with Triton $X-100$. The variation of peak height was observed.

In another blood experiment, diluted CDC (Communicable Disease Center, Atlanta, Georgia) samples were compared to a human blood lead standard cưrve which was diluted with standard amounts of lead to give $0,0.05,0.10$ and $0.15 \mathrm{mg} / \mathrm{l}$. These samples were prepared in the following way:

\section{Working standard (1 mg/l)}

Dilute a $0.10 \mathrm{ml}$ of a $1.0 \mathrm{~g} / \mathrm{l}$ stock $\mathrm{Pb}$ standard to $100 \mathrm{ml}$ in a-poly= propylene volumetric flask with distilled deionized water. The working standard is used for preparation of the standard curve.

\section{Standard curve}

Normal whole blood $(0.1 \mathrm{ml})$ is pipetted in a reverse manner because of its viscosity into 4 tubes.

Túbe $1(0 \mathrm{mg} / \mathrm{l}): 0.9 \mathrm{ml}$ deionized water.

Tube $2(0.05 \mathrm{mg} / \mathrm{l}): 0.85 \mathrm{ml}$ deioniżèd wàtër and $0.05 \mathrm{ml}$ of working standard.

Tube $3(0.1 \mathrm{mg} / \mathrm{l}): 0.80 \mathrm{ml}$ deionized water and $0.1 \mathrm{ml}$ working standard.

Tube $4(0.15 \mathrm{mg} / \mathrm{l}): 0.75 \mathrm{ml}$ deionized water and $0.15 \mathrm{ml}$ working standard.

The CDC samples are bovine whole blood collected after lead nitrate has been orally administered. Three blood samples with various lead levels are sent quarterly to laboratories participating in the survey. The standard addition curve was adjusted by subtracting the endogenous amounts of lead from each point on the curve. A value was assigned to the $C D C$ sample from the human blood curve. This result was compared to the lead value obtained from standard additions by adding standard amounts of lead directly to the $C D C$ blood to give concentrations of $0,0.05,0.10$, and $0.15 \mathrm{mg} / \mathrm{l}$. The dilutions for the standard additions were done the same way as with normal blood. A five microliter aliquiot of the diluted specimen was transferred to the Hitachi cup -type cuvette and analyzed in duplicate using the instrument conditions listed in table 1. Because of the viscous nature of blood, ramping of the drying and ashing steps were essential. Atomization temperatures below $2400^{\circ} \mathrm{C}$ led to incomplete atomization and also lower absorption values. Analysis of the NBS bovine liver standard by standard addition give results within $98 \%$ of the value found by NBS. The coefficient of variation for blood lead, urine lead and the sensitivity of these measurements, have been previously determined by Pleban \& Pearson (3).

Tab. 1. Zeeman atomic absorption spectrometry parameters for lead analyses.

\begin{tabular}{ll}
\hline Whole blood lead & Urine lead \\
\hline Dry: ramp-1.0 amp/s & ramp-1.0 amp/s \\
$20 \mathrm{~A}\left(110^{\circ} \mathrm{C}\right)$ & $20 \mathrm{~A}\left(110^{\circ} \mathrm{C}\right)$ \\
Ash: ramp-2.0 amp/s & ramp-2.0 amp/s \\
$60 \mathrm{~A}\left(360^{\circ} \mathrm{C}\right)$ & $60 \mathrm{~A}\left(350^{\circ} \mathrm{C}\right)$ \\
Atomize: step-7.5 s & step-7.5 s \\
$290 \mathrm{~A}\left(2400^{\circ} \mathrm{C}\right)$ & $290 \mathrm{~A}\left(2400^{\circ} \mathrm{C}\right)$ \\
Ar carrier gas: $200 \mathrm{ml} / \mathrm{min}$ & $200 \mathrm{ml} / \mathrm{min}$ \\
Ar sheath gas: $4-1 / \mathrm{min}$ & $4-1 / \mathrm{min}$ \\
Wavelength: $283.3 \mathrm{~nm}$ & $283.3 \mathrm{~nm}$ \\
Band pass: $1.1 \mathrm{~nm}$ & $1.1 \mathrm{~nm}$ \\
Scale expansion: 0.1 absorbance units & $0.3 \mathrm{absorbance}$ units \\
Pen response: Fast $(1)$ & Fast $(2)$ \\
Lamp current: $12.5 \mathrm{~mA}$ & $12^{\circ} .5 \mathrm{~mA}$ \\
\hline
\end{tabular}




\section{Urine lead experiments}

Urine $(0.5 \mathrm{ml})$ was added to $0.45 \mathrm{ml}$ of deionized water and then spiked with $0.05 \mathrm{ml}$ of the working lead standard $(1 \mathrm{mg} / \mathrm{l})$ to give a final concentration of $0.05 \mathrm{mg} / \mathrm{l}$. The working lead standard was prepared in the same way as in the blood lead procedure. A five microliter aliquot of the diluted specimen is then transferred by reverse pipetting to the graphite cup-type cuvette and analyzed in duplicate according to the conditions in table 1 . Ramping was necessary for the drying and ashing stages. Otherwise, incomplete drying and ashing occurred. Temperatures less than $2400^{\circ} \mathrm{C}$ lead to incomplete atomization and also lower absorption values.

In one experiment, the absorption of $0.05 \mathrm{mg} / \mathrm{l}$ of lead in water was compared to the urine with only lead added or urine with lead and a final concentration of $1.0 \mathrm{~g} / 1$ Triton $X-100,50 \mathrm{~g} / 1$ Ultrex $\mathrm{HNO}_{3}$ (diluted from $700 \mathrm{~g} / \mathrm{kg}$ Ultrex with deionized distilled water) or $50 \mathrm{~g} / 1\left(\mathrm{NH}_{4}\right)_{2} \mathrm{HPO}_{4}$.

Because of the marked suppression of the lead absorption signal by urine, an attempt was made to find if various ions. are the source of this suppression. Because of the suppression of the lead absorption signal by urine, the ion experiments were done in water. The ions tested were calcium, chloride and magnesium. The ions were added to water containing $0.05 \mathrm{mg} / \mathrm{l}$ of lead. Magnesium was tested at $10,20,40,80$ and $100 \mathrm{mg} / \mathrm{l}$, and chloride as sodium chloride at two concentrations of 18,25 and $36.5 \mathrm{~g} / \mathrm{l}$. Both the calcium and the magnesium had nitrate as their anion.

Because of the marked enhancement of the lead signal by $\left(\mathrm{NH}_{4}\right)_{2} \mathrm{HPO}_{4}$ at $50 \mathrm{~g} / \mathrm{l}$, other concentrations, ranging from 0 to $100 \mathrm{~g} / \mathrm{l}$ were also tested.

\section{Results}

Table 2 shows the comparison between the two standard addition procedures. At all levels, procedure $B$ or lead added directly to bovine CDC blood showed the closest mean to that of the CDC survey samples. The results from procedure $B$ were only $0.3,2.5$ and $0.4 \%$ higher than the $C D C$ survey results. On the other hand, procedure $A$, where the lead in the CDC sample was compared to the human blood standard cuirve, the results were $15.0,12.8$ and $10.8 \%$ greater than the CDC survey results. Similar results were observed after a second series of three CDC samples were analyzed by the two procedures.
Table 3 shows the reproducibility of the peak height from the lead of a bovine CDC blood and a human blood sample with and without Triton X-100. The peak heights of both the bovine and the human blood sample were greater with samples containing Triton X-100 than similar samples without Triton X100. In addition, the peak height without the Triton $X-100$ showed twice the variability than the sample with Triton X-100.

Tab. 3. Reproducibility of a bovine CDC blood and a human blood sample with and without $1.0 \mathrm{~g} / 1$ Triton $\mathrm{X}-100$.

\begin{tabular}{llll}
\hline Sample & $\begin{array}{l}\text { Triton } \\
\mathrm{X}-100\end{array}$ & $\begin{array}{l}\text { No. } \\
\text { of trials }\end{array}$ & $\begin{array}{l}\text { Peak height } \\
(\mathrm{mm}) \pm \text { S.D. }\end{array}$ \\
\hline Bovine-CDC & + & 17 & $25 \pm$ \\
Bovine-CDC & - & 14 & $14 \pm 6.75$ \\
Human & + & 21 & $24 \pm 2.2$ \\
Human & - & 20 & $16 \pm 4.75$ \\
\hline
\end{tabular}

With urine (tab.4), Triton X-100 showed no increase in the lead signal. Nitric acid only increased the peak height to a small extent. However, $50 \mathrm{~g} / \mathrm{l}$ $\left(\mathrm{NH}_{4}\right)_{2} \mathrm{HPO}_{4}$ markedly increased the lead signal height of the three urines. In another experiment to

Tab. 4. Effect of lead peak height in three patients' urines by adding $\left(\mathrm{NH}_{4}\right)_{2} \mathrm{HPO}_{4}$, Triton $\mathrm{X}-100$, and $\mathrm{HNO}_{3}$ to urine containing $0.05 \mathrm{mg} / \mathrm{l}$ of lead.

\begin{tabular}{|c|c|c|c|}
\hline \multirow[t]{2}{*}{ Additiọn } & \multicolumn{2}{|c|}{ Peak height $\left.{ }^{*}\right)(\mathrm{mm})$} & \multirow[b]{2}{*}{ Patient 3} \\
\hline & Patient 1 & Patient 2 & \\
\hline None & 1.0 & 0.0 & 0.0 \\
\hline Triton $\mathrm{X}-100,1.0 \mathrm{~g} / \mathrm{l}$ & 1.0 & 0.0 & 1.0 \\
\hline $\mathrm{HNO}_{3}, 50.0 \mathrm{~g} / \mathrm{l}$ & 4.5 & 1.0 & 2.0 \\
\hline$\left(\mathrm{NH}_{4}\right)_{2} \mathrm{HPO}_{4}, 50 \mathrm{~g} / 1$ & 15.6 & 10.5 & 12.4 \\
\hline Lead in $\mathrm{H}_{2} \mathrm{O}, 0.05 \mathrm{mg} / \mathrm{l}$ & 14.9 & 14.9 & 14.9 \\
\hline
\end{tabular}

*) Average of 10 trials

Tab. 2. Comparisons of two lead standard addition procedures.

\begin{tabular}{|c|c|c|c|c|c|c|c|c|}
\hline CDC samples & $\begin{array}{l}\text { Mèàn } \\
\text { CDC̣*) } \\
\text { value } \\
\text { (mg/l) }\end{array}$ & $\begin{array}{l}\text { Range } \\
\text { (mg/l) }\end{array}$ & $\begin{array}{l}\text { Procedure } A^{* *} \text { ) } \\
(\mathrm{mg} / \mathrm{l})\end{array}$ & $\begin{array}{l}\text { Average } \\
\text { (mg/l) }\end{array}$ & $\%$ high & $\begin{array}{l}\text { Procedure } \mathrm{B}^{* *} \text { ) } \\
\text { (mg/l) }\end{array}$ & $\begin{array}{l}\text { Average } \\
\text { (mg/l) }\end{array}$ & $\%$ high \\
\hline $\begin{array}{l}\text { DE8-CO1 } \\
\text { DE8-CO2 } \\
\text { DE8-CO3 }\end{array}$ & $\begin{array}{l}29 \\
53 \\
54\end{array}$ & $\begin{array}{l}22-35 \\
45-61 \\
46-62\end{array}$ & $\begin{array}{l}35,34,30,34 \\
59,63,59,58 \\
45,63,57,65\end{array}$ & $\begin{array}{l}33.3 \\
59.8 \\
59.8\end{array}$ & $\begin{array}{l}15.0 \\
12.8 \\
10.8\end{array}$ & $\begin{array}{l}31,32,27,29 \\
49,52,57,59 \\
53,53,56,55\end{array}$ & $\begin{array}{l}29.8 \\
54.3 \\
54.2\end{array}$ & $\begin{array}{l}0.3 \\
2.5 \\
0.4\end{array}$ \\
\hline
\end{tabular}

*) survey result

**) Comparison of bovine CDC samples to a standard curve which uses human blood with standard amounts of lead added.

***) Lead added directly to bovine CDC blood. 
determine the optimal peak height (fig. 1),the results were essentially the same down to $10 \mathrm{~g} / \mathrm{l}$ $\left(\mathrm{NH}_{4}\right)_{2} \mathrm{HPO}_{4}$. At $5.0 \mathrm{~g} / \mathrm{l}$, the peak height started to drop. A marked decrease was seen at $4.0 \mathrm{~g} / \mathrm{l}$. Up to $3.0 \mathrm{~g} / \mathrm{l}$, no increase of absorption was observed.

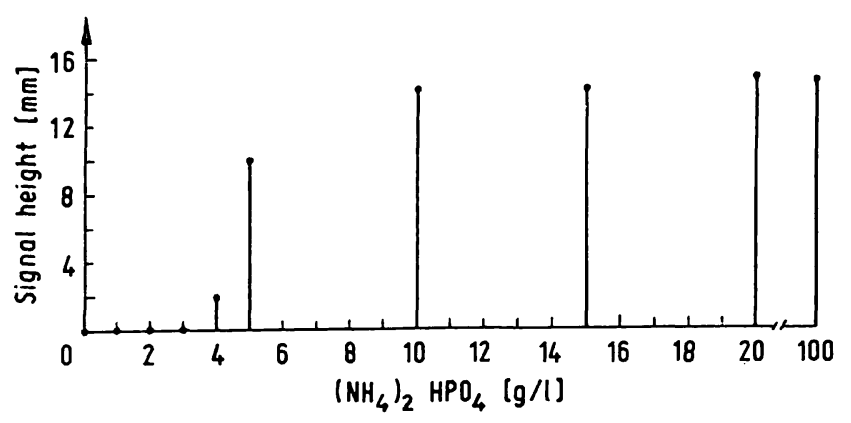

Fig. 1. Effect of increasing $\left(\mathrm{NH}_{4}\right)_{2} \mathrm{HPO}_{4}$ concentration on the lead signal height of $0.05 \mathrm{mg} / \mathrm{l}$ of lead in urine.

Calcium and chloride had no effect on the signal height produced by lead in water (tab. 5), but magnesium decreased the height of the absorption peak of lead.

Tab. 5. Calcium*), magnesium**) and chloride***) effect on lead signal height of $0.05 \mathrm{mg} / \mathrm{l} \mathrm{Pb}$ in water.

\begin{tabular}{lcl}
\hline Ion & $\begin{array}{l}\text { Concentration } \\
(\mathrm{mg} / \mathrm{l})\end{array}$ & $\begin{array}{l}\text { Signal height } \\
(\mathrm{mm})\end{array}$ \\
\hline $\mathrm{None}$ & - & 29.5 \\
$\mathrm{Ca}$ & 50 & 31.0 \\
$\mathrm{Ca}$ & 100 & 31.5 \\
$\mathrm{Ca}$ & 200 & 35.5 \\
$\mathrm{Ca}$ & 300 & 31.0 \\
$\mathrm{Ca}$ & 950 & 30.5 \\
$\mathrm{Mg}$ & 10 & 30.5 \\
$\mathrm{Mg}$ & 20 & 28.5 \\
$\mathrm{Mg}$ & 40 & 24.3 \\
$\mathrm{Mg}$ & 80 & 21.2 \\
$\mathrm{Mg}$ & 100 & 20.6 \\
$\mathrm{Cl}$ & 17800 & 29.7 \\
$\mathrm{Cl}$ & 35600 & 31.0 \\
\hline
\end{tabular}

*) Ca normals, $50-150 \mathrm{mg} / \mathrm{l}$ urine

**) $\mathrm{Mg}$ normals, $14-290 \mathrm{mg} / \mathrm{l}$ urine

***) Cl normals, $3905-8875 \mathrm{mg} / \mathrm{l}$ urine

\section{Discussion}

Although it is known that comparisons between much different matrices such as blood and urine are dramatically different, matrix effects by one type of blood are assumed to be about the same as another type. About a $10-15 \%$ difference does arise by comparing the $\mathrm{CDC}$ bovine blood matrix to a human blood standard matrix. Although $10 \%$ is not a great amount, this percentage was enough to move three of the twelve samples done by procedure $A$ in table 2 . out of the acceptable range. In addition, six of twelve samples are barely within range.

Triton $\mathrm{X}-100$ is known as a surface acting agent and may spread the sample better in the graphite cuvette before atomization. The sample may also not be sticking to the porous graphite cuvettes as samplès without Triton $\mathrm{X}-100$. If some lead does stick the graphite cuvette, some of this retained lead may be released on the next atomization thus leading to the larger variance seen in table 3 in samples without Triton X-100. We observed this phenomenon during the analysis. If one peak height was lower, the next peak height was usually greater by a similar amount.

Calcium and chloride had no suppressive effect on the aqueous lead peak height, but maagnesiụm showed some interference on lead analyses (tab. 5). Manning \& Slavin, using a graphite furnace (4), havie demonstrated suppression of the lead signal by magnesium. The substance in the urine which markedly suppresses the lead peak height in our experiments, may be partially due to magnesium.

Phosphate ion does markedly reduce the suppression of the lead signal by urine. Hinderberger et al. (5) have previously observed that diammonium hydrogen phosphate enhances the lead signal in urine, serum, and other biological matricès. Because phosphate ion increases the lead signal, much greater sensitivity for lead analysis could be achieved by rou= tinely adding phosphate ion to urine specimens.

The Zeeman effect atomic absorption theoretically offers more accurate and reproducible background correction than the deuterium lamp at all wavelengths. The deuterium lamp background requires that both the intensity and beam alignment of the hollow cathode tube and the deuterium lamp be matched (6). Wavelengths below $200 \mathrm{~nm}$ and above $350 \mathrm{~nm}$ are difficult to correct due to the emission characteristics of the deuterium lamp. Disadvantages of the Zeemari effect are found with sensitivity and the analytical working range (7). The relative absorbance of Zeeman instruments are somewhat less than standard atomic absorption instruments and at high concentrations, the analytical curve turnes downward, back toward the concentration axis. 


\section{References}

1. Needleman, H. L., Gunnoe, C., Leviton, A., Reed, R., Peresie, H., Maher, C. \& Barrett, P. (1979) N. Engl. J. Med. 300, 689-695.

2. Koizumi, H., Yasuda, K. \& Katayama, M. (1977) Anal. Chem. 49, 1106-1112.

3. Pleban, P. A. \& Pearson, K. H. (1979) Anal. Letters 12, 939-950.
4. Manning, D. C. \& Slavin, W. (1978) Anal. Chem. 50', 1234-1238.

5. Hinderberger, E. J., Kaiser, M. L. \& Koirtyohann, S. R. (1981) At. Spectrosc. 2, 1-7.

6. Kahn, H. L. (1968) At. Absorpt. Newsl. 7, 40-45.

7. Fernandez, F. J., Myers, S. A. \& Slavin, W. (1980) Anal. Chem. 52, 741-746.

\section{Raymond J. Shamberger Department of Biochemistry The Cleveland Clinic Foundation 9500 Euclid Avenue Cleveland, Ohio 44106 U.S.A.}




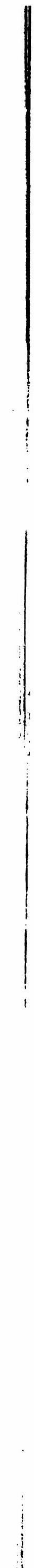

